\title{
Twitter, the End of Bipartisan Politics and the Rise of Populism. The Spanish Campaign in May 2015
}

\section{Revista de Sociologia e Política}

DOI 10.1590/1678-987319277107

\author{
Roberto Gelado-Marcos'ii , Belén Puebla-Martínez"iD \\ e Rainer Rubira-Garcíall' id \\ IFacultad de Humanidades y Ciencias de la Comunicación Universidad San Pablo, CEU, Madrid, España. \\ "IFacultad de Ciencias de la Comunicación Universidad Rey Juan Carlos, Madrid, España.

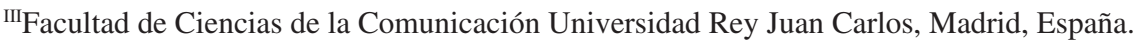

\begin{abstract}
Introduction: The seemingly unshakable bipartisan political system in Spain started to crumble in the wake of the European Elections of 2014, giving way to a more fragmented distribution of seats. Such process crystallised in the Regional Elections of 2015, highlighting an already anticipated decay of traditional parties PP and PSOE and rise of populist parties like Podemos. Materials and Methods: Focusing on the discourse of Spanish politicians on Twitter, as one of the most recent political communication tools politicians had to learn to deal with, this paper offers a triangulation of quantitative and qualitative analysis. Results: We discuss, from a communication perspective, similarities and differences among parties and politicians on whether communication 2.0 changed and/or enriched political discourse leading up to a redistribution of parliamentary seats. Discussion: This paper stress the impact of social networks and the implementation of different communication strategies to address the collapse of bipartisanship in Spain.
\end{abstract}

KEYWORDS: Twitter, bipartisanship, communication, campaign, Spain.

Received in October 6, 2018. Revised in June 5, 2019. Accepted in July 6, 2019.

\section{Introduction ${ }^{1}$}

\footnotetext{
${ }^{1}$ We thank the anonymous reviewers of the Revista de Sociologia e Política for their comments on this article. This work was supported by the XI CEU-Santander Bank Program for Research Mobility and the XII USPCEU Program for Institutional Mobility.
}

$\mathrm{W}$ ithin the Spanish context, Twitter broke onto the political stage during the 2011 electoral campaign, though Deltell (2012) has questioned its effectiveness in voting terms. He suggests that small parties tend to commit more and better with 2.0 communication strategies, though their efficiency is not necessarily followed by an increase in their voting intentions. Several studies have addressed the significance of 2.0 political communication and information quality in digital media in one way or another in different contexts (Romero-Rodríguez et al., 2015; Romero-Rodríguez et al., 2016; Espinel et al., 2018). What happened after the 2011 electoral campaign, starting with the European Elections of 2014, confirmed the beginning of the end of the traditional bipartisan distribution of parliamentary seats. That process crystallised in the following Regional and Local Elections, which at the same time, preceded the surprising -in the light of traditional bipartisanship, at least-irruption of alternative political forces in the Spanish national parliament a few months later.

But, how and why did this all happen? Part of the newly represented parties invoked the importance of social networks in spreading the message, and this is precisely the starting point of our investigation. One of the central questions addressed in this research states: 'Is Twitter more and better used by the so-called underdogs?' The underdogs would be those political parties that were not likely to win elections not so long ago but came as a feasible alternative, especially after the European and Regional Elections-. The 'big fish', the two main political parties whose prominence in the political scene has been severely questioned by citizens in recent elections, would be the traditional parties whose communication strategies in Twitter would be confronted to those of the 'underdogs'. 
The 'big fish' are represented in Spain by the two big traditional parties: Partido Popular (PP) on the conservative side and Partido Socialista Obrero Español (PSOE) on the socialist side.

Our main focus lies on a comparison of the Twitter activity by the two big traditional parties and the two main alternatives (left wing -Podemos- and liberal -Ciudadanos-) that consolidated after the Local and Regional Elections that took place on May $24^{\text {th }}, 2015$. Thus, the main goal is to determine both quantitatively and qualitatively if there are significant differences in their use of Twitter, both at an inter-level (big fish Vs underdogs) and (differences between PP \& PSOE, and also between Podemos \& Ciudadanos).

The study focuses specifically on the use of Twitter by Spanish politicians, as it is one of the increasingly preferred vehicles of communication for most parties to reach their citizens. This root on the on-going academic debate on the ways Twitter is reshaping politics nowadays and aims at providing a methodological framework that can be implemented in future investigations in the field. Our results discuss the relevance of Internet and social media in relation to democratic praxis taking into account approaches from authors such as Chadwick \& Stromer-Galley (2016), Coleman (2017), Coleman \& Freelon (2015) and Stromer-Galley (2014). Regarding the time framework, the investigation focused on one of the most vivid periods of political activity in Spain in 2015, the Local and Regional Elections of May $24^{\text {th }}$, which, for many, ignited the change of the political landscape in Spain that would consolidate in the General Elections of December $20^{\text {th }}$.

Data from the tweets published by the four main actors of the Spanish political scene (@marioanorajoy, @ sanchezcastejon, @Pablo_Iglesias_@Albert_Rivera), were retrieved via Nvivo's addon NCapture and later analysed with a computer assisted design of investigation that leaned on content analysis, and language and textual analysis as the main sources to reach relevant conclusions from both quantitative and qualitative approaches.

\section{Context of study: Regional and Local Elections of 2015}

On May $24^{\text {th }} 2015$, Regional Elections were held in thirteen out of the seventeen Spanish autonomous communities and also Local Elections took place that same day in all the municipalities of the country. Following data of the Spanish Home Office, 22.746.489 Spaniards (64,93\% of the total population) voted that day. Although Partido Popular was the most voted force, their massive loss of votes -which hit, though significantly less, PSOE too- pointed at the new forces, notably Podemos and Ciudadanos, as the true winners of the electoral process.

The conservative party (PP) gained the absolute majority in 2,768 municipalities and relative majority in 656, whereas the Socialist party (PSOE) reached the absolute majority in 1,937 municipalities and relative majority in 537. Ciudadanos obtained more than a million and a half votes -it was the third party with more votes nationwide-, reached the absolute majority in 48 municipalities, and the relative majority in 21 .

Podemos did not, strictly speaking, participate in the Elections; although some local parties (such as Ahora Madrid in the capital city, Barcelona en Comú in the capital of Catalonia, or Zaragoza en Común, to name but a few) were publicly supported by them.

Although the Partido Popular led the voting ranking, they lost 2.5 million votes from the previous Local Elections, and even though in some cities they were the most voted party, they ended up losing the town hall. 


\section{Methods}

We found two main decisions that had to be adopted prior to the implementation of the language and textual analysis in order to properly frame the investigation: the number and nature of the accounts to be studied and the time framework submitted to study. Regarding the former, we determined to narrow down the subject of our study to the four Twitter accounts of the main political leaders of the four main parties that, which following the results of the Local and Regional Elections in May, seem likely to monopolise voting intention in Spain in the leading up to the next General Elections: Mariano Rajoy (Partido Popular, PP), Pedro Sánchez (Partido Socialista Obrero Español, PSOE) -as representing the more represented traditional parties-, Pablo Iglesias (Podemos), and Albert Rivera (Ciudadanos, Cs) -visible faces of the most supported emerging forces-.

Regarding the time framework, the study focused mainly on one of the most vigorous periods of political activity in 2015, marked by the beginning (May $8^{\text {th}}$ ) and end (May 22 $2^{\text {nd }}$ ) of the electoral campaign for the Local and Regional Elections. However, in order to enlarge the amount of tweets submitted to study to a sample size of at least 1,000 textual units, the final time frame was expanded both at the end, with May $25^{\text {th }}$ set as the definite final date, and May $5^{\text {th }}$ as the final starting point, which added an extra week to the time frame that was initially considered.

In order to retrieve the tweets of the aforementioned accounts effectively we used Nvivo 10 software, which allowed us to configure an exhaustive corpus of study that could be analysed both quantitative and qualitatively with language and content analysis as the technique upon which everything else will hinge.

Thus, through Nvivo we retrieved all the tweets produced by the four party leaders submitted to study (@marioanorajoy, @ sanchezcastejon, @Pablo_Iglesias_@ Albert_Rivera) between May $5^{\text {th }}$ and May $25^{\text {th }}$ of 2015. Before delving into further analysis, this approach already provided us with a first approach to how active they were on Twitter during the campaign. This initial quantitative approach was computer-assisted by Nvivo itself.

There are some issues, though, that cannot be addressed from a quantitative point of view because. Hence our methodological proposal triangulates (Lewis-Beck et al., 2004) between the mere quantitative analysis and a more qualitative approach that escalates to a more inclusive understanding of language in (real) action, a field where language and textual analysis (Paltridge, 2012) is definitely more supportive.

\section{Twitter and Spanish Political Activity in Election Times}

Approaching their activity during the three weeks submitted to study (May $5^{\text {th }}$ - May $25^{\text {th }}$ ) from a quantitative point of view, there are remarkable differences in how each politician uses Twitter. The most active account in Twitter among the four politicians submitted to study is Mariano Rajoy's, with 388 tweets in the 21 days studied, followed by Albert Rivera (358 tweets), Pedro Sánchez (261) and Pablo Iglesias (182). However, a closer insight on the production of tweets reveals a far less enthusiastic use of Twitter than the initial figures may suggest.

Rajoy's account, for instance, is the only one that makes a difference between the tweets that are personally written by himself and those that are edited by his team (the difference being a two-character signature -MR-at the end of the customised messages). Running an exact text search in NVivo reveals that 
only 10 tweets out of the 388 published during the span of time studied (roughly $2,6 \%$ of the total tweets) are signed personally by him.

IV.1 Mentions and hashtags

A more detailed assessment of the goals Spanish politicians have in mind when using Twitter also reveal notable differences. To begin with, the second category we established when analysing speeches, 'Mentions and hashtags', offers interesting insights on the type of discourse built by Spanish politicians. In all the Twitter accounts studied, the amount of tweets with self-mentions, mentions to the politician's party exceeds largely the amount of mentions to others. And, although this general rule applies to all of them, there are revealing differences among the politicians studied.

Mariano Rajoy (PP) is, by large, the politician whose account includes more self-mentions in total of all four submitted to study: 138. More than one out of three tweets $(35,6 \%)$ published by the conservative leader includes a mention to himself. However, in relative terms, the proportion is even bigger when examining Socialist Pedro Sanchez's account, whose 99 self-mentions mean that $37,9 \%$ of the total amount of tweets refer to himself straightaway. The ratio drops significantly when looking at the runner-up parties: self-mentions in Rivera's account exceed slightly one out of every four tweets he produces $(27,4 \%)$, and falls a bit below that edge $(24,7 \%)$ in Iglesias' account.

The landscape is slightly different if we look at the mentions to the politicians' own parties. Mariano Rajoy (PP) mentions his own party 99 times -slightly more than 25\% of his tweets-, whereas Sánchez (PSOE) does it 92 times, which in relative terms constitutes a more noteworthy $35,2 \%$ of his tweets. In total terms, however, it is Albert Rivera (C's) who leads the rank of mentions to his own party, with 133 , which also makes him the most enthusiastic politician when mentioning his party in relative terms $(37,2 \%)$. Pablo Iglesias (Podemos) only mentions his own party 26 times (14,3\%).

Regarding the mentions to the other three parties or politicians coming from these other parties, for instance, neither Albert Rivera (C's), nor Pablo Iglesias (Podemos) or Mariano Rajoy (PP) concede a remarkable share of their political discourse to their political adversaries. There are only 36 mentions (a bit more than $10 \%$ of his Twitter production during the time studied) to PP, PSOE, and Podemos in Albert Rivera's account, which distributes the mentions in quite a balanced fashion (12 to Podemos, 13 to PP and 11 to PSOE). Pablo Iglesias (Podemos) devotes 15 out of his 17 mentions to political adversaries to PP. And, if Iglesias' mentions to political adversaries barely reaches $10 \%$, far from the almost 25\% of his self-mentions, Rajoy (PP) saves even less room for other parties: only 4 mentions out of his 388 tweets, which suggests a strategy that attempted not to publicise his adversaries by giving them notoriety in his own account.

Sanchez' strategy of mentioning other politicians and parties is diametrically opposed to Rajoy's approach -and, to a great extent, Rivera's and Iglesias'. The Socialist leader only mentions runner-up Iglesias (Podemos) and Rivera (C's) three times each, but he mentions PP and PP-related politicians up to 80 times, only 12 times less than his own party and 19 times less than he mentions himself. Almost one in three tweets by Sánchez (PSOE) includes a mention to his right-wing counterpart, with notable references to corruption cases.

There are significant differences, though, in the mentions to outsiders in Rivera's and Iglesias' accounts. Although both of them still mention themselves, their parties and their political opponents more than any other, mentions to other figures are much more frequent in both the accounts of the leaders of 
Ciudadanos and Podemos. Iglesias' mentions outside the pure political arena are mainly media-related, but highly politicised.

Albert Rivera (C's) leaves a much wider space - 68 mentions, almost $20 \%$ of his total production of tweets- for participation to other social actors outside himself, his party, and his opponents. Most of them are media sources -from which most are there because they publicise his campaign in one way or another-, but the ideological spectrum is much more varied.

The use of hashtags has been not only a second aspect that helps analysing how Twitter fits in the politicians' strategy, but also reveals differences in the understanding of the tool that the politicians studied have. If mentions stimulate the debate by trying to involve specific individuals or organisations, hashtags are the way Twitter proposes to engage unknown individuals in the debate. And, in terms of speech analysis, they reveal what topics are important enough for the politician to try and make sure that anyone interested in the topic can jump into the debate they propose.

Hashtags in the four accounts studied and during the time span analysed focus mainly and clearly on the elections. We divided the analysis in four groups, three of which (elections, governmental actions, and other political topics) have to do with Politics one way or another; whereas the fourth -simply 'Others'tried to clarify which other debates aside of pure Politics the politicians were trying to stimulate. Surprisingly enough, only Mariano Rajoy's account engaged more actively in debates outside the political arena. All the other hashtags he used and, more importantly, any of the other candidates used, have to do with Politics.

Election time clearly marks the agenda, as proved by the fact that it is the only category of hashtags that is present in the discourses of all politicians studied. Rajoy's discourse is not only the most profuse when using hashtags (137), but also the most consistent in circulating their two main campaign mottos, \#trabajarhacercrecer (Working, making, growing) and \#votapp (Vote for PP).

Albert Rivera (C's) also uses hashtags abundantly -123 in 358 tweets, slightly more than one hashtag every three tweets-, but also draws a more varied and less adamant scheme of hashtags. Unlike Rajoy's account, where only three hashtags are mentioned more than 5 times during the 21 days studied (the third being \#24m, the Election day), Rivera's consistency distributes the attention span around to up to seven hashtags that exceed the 5 mentions. Most of the recurring hashtags hinge upon two very simple ideas: the corporate colour of the party -orange-, which is included in the most-referred to hashtag, \#tournaranja; and the notion of change which, as we will see in the thematic and linguistic analysis of the tweets, is key to Rivera's political discourse during the electoral campaign.

Pablo Iglesias (Podemos) and Pedro Sánchez (PSOE) are less insistent in their use of hashtags, but with different strategies. Whereas Iglesias (Podemos) reverberates Rivera's echoes of the plea for a change -though using the word 'ahora' (now) as the motto-, Sánchez (PSOE) opts -just as Rajoy (PP)- for more vote-oriented hashtag style. His top-ranked hashtag spreads the campaign slogan, Gobernar para la mayoría (Ruling for the majority), which is mentioned up to 34 times; but the common factor in many other hashtags by Sánchez (PSOE) are mere interpellations to vote for his party.

The other two categories of hashtags, 'Governmental activities' and 'Other political topics' are almost as ancillary as the general 'Others' aside Politics that we commented before: only Mariano Rajoy (PP) and Pedro Sánchez (PSOE) has hashtags included in any of these two categories and only Rajoy (PP) has examples in both of them. Both Rajoy (PP) and Pedro Sánchez (PSOE) use 
three times the hashtag \#sesiondecontrol, and Rajoy (PP) informs about agreements reached by his cabinet in the council of ministers with the hashtag \#CMin (quoted 18 times). Finally, Rajoy (PP) is the only politician that uses hashtags to code tweets about other political topics not strictly related to governmental actions or election time.

\section{IV.2 Elections}

Rajoy's account makes a special effort in keeping PP's electorate updated through references (29) to a series of live material Twitter users can access to that are related to their campaign activities -and which are not produced by Rajoy (PP) himself, but are simply retweets from his party's account. Aside of the aforementioned use of hashtags by the conservative party in relation to the Election period (mostly encouraging the electorate to vote for them quite straightaway), Rajoy (PP) uses Twitter as -mainly- a showcase of the political repercussion of his party's events, and -ancillary- an informative tool about what Rajoy (PP) has done at a national level during his almost four years as a Prime Minister. And again, most of Rajoy's messages about the Elections are not produced by his account, but are mostly retweets of different accounts of his party.

The Socialist leader Pedro Sánchez (PSOE) also opts for using Twitter as a showcase of information when talking about the Elections but, unlike Rajoy (PP), his account not only retweets what his party says, but also produces messages of his own. Most of them hinge upon, as will be further discussed later on in relation to the 'political language' category, the notion of change, the ideological implications of voting for his party (equality, working rights, social services, welfare state, decent jobs, etc.), and even metaphorical interpellations to his electorate.

Albert Rivera (C's) uses his references to the Electoral process both to stress the need for a change and, especially, to let the electorate know about the multiple political rallies he is taking part in. In this more promotional approach to the topic of the Regional and Local Elections, Rivera (C's) stresses the need for a change too, but also echoes the prospective of good results for his party and never stops praising how valuable the members of his party in the cities he is visiting -and rallying in- are.

Pablo Iglesias (Podemos), for his part, attempts to personalise his coverage of the Elections with fewer retweets than some of his counterparts, and conveys a discourse focused on the notion of change (and a certain sense of urgency of History calling the Spanish electorate), comparisons with the ruling party, reaffirmation of political standings (full support to an increase of the coverage of the National Health System), support to unofficial Podemos' candidacies (such as Manuela Carmena, from Ahora Podemos, in Madrid), and even emotional gestures such as the presence of Iglesias' father in a political rally in Zamora -which he emphasises with a picture of the moment.

\section{IV.3 Political topics}

Rajoy (PP) is, indeed, who more insistently tweets about political issues, with 285 references to topics not directly related to Elections in his 388 tweets -which imply that there are at least three references to political issues that do not address specifically the Elections in every four tweets Rajoy (PP) publishes. Pedro Sánchez (PSOE) mentions political issues 117 times -so hardly $45 \%$ of his tweets contain a reference of this kind-; but, surprisingly enough, Albert Rivera (C's) and Pablo Iglesias (Podemos) hardly reach the edge of $25 \%$ of their tweets including a reference to the political landscape aside of the Elections. 
Rivera (C's) covers issues of political interest aside of the Elections 78 times (hardly 22\% of his total tweets) and Iglesias (Podemos) only shows explicit interest on political issues through his tweets -again, aside the Elections- 27 times (his percentage falls below the $15 \%$ edge if we compare it with the total amount of tweets he publishes).

The economic growth, in general, is mentioned 17 times, whereas general mentions to the importance of economy receive 7 mentions, and there are also more specific references to the automobile sector (5), private businesses (5), and exportations (3). Finally, there is an important focus on social policies in Rajoy's discourse in Twitter (33 mentions), with a special emphasis on Family (20) -which he literally labels as 'a priority'- and Equality (12, 6 of which refer specifically to equality for disabled people); and there are less frequent references to Europe (16 mentions), Demography (the Youth is mentioned 9 times and Pensions, twice), the Spanish Constitution (6 mentions), and Sports (3 mentions).

Although his focus on political topics outside the elections is not so productive as Rajoy (PP), Sánchez (PSOE) is still quite active if we compare his timeline to Rivera's or Iglesias'. The Socialist leader shares with Rajoy (PP) a concern in the Economy (23 mentions, barely a 10\% of his total tweet production), although his approach to recovery tends to emphasise the long-lasting effects of the crisis ( 9 mentions) and a galloping problem of unemployment (10), as well as some reminders of the recent cuts in social services (4).

His focus on other topics, although he stresses his commitment to the notion of Spain as a great nation with 19 mentions -3 of which, though, question the organisation of Spain as a modern State and advocates for a more federal organisation-, differ greatly from Rajoy (PP), though. He tweets 44 times about Social Policies, and almost half of them (19) refer to equality issues, which in relative terms reveal a higher presence of the topic in his discourse $(7,3 \%$, as opposed to $3 \%$ in Rajoy's tweets). His emphasis on the Family as a key social institution is not so frequent (6 mentions, roughly a third of Rajoy's), although he is keener in spotting Social Policies in general (7 mentions), Health (7), and Public Services (5).

Sánchez' interests within political issues lie also in Corruption (19 explicit mentions, though the topic is present secondarily in other messages), Culture (6, 3 of which refer to bullfighting), Demography (19, 13 of which are direct interpellations or mentions to the Young people), Education (8), and Civil Rights (4).

The main axis of Rivera's discourse when the focus switches from Election time to general political issues is clear: Spain. 60 out of his 78 references $(76,9 \%)$ to political issues outside the Elections include a specific address to Spain and Spaniards, also -as in Rajoy's discourse- generally in a praising tone. The only other focus of interest of Rivera (C's) when referring to Politics -outside the elections- is shared not with Rajoy (PP) but with Sánchez (PSOE) -and, as we will see, Iglesias (Podemos): corruption (8 mentions). Education, with 6 mentions, and primary elections, with 4, complete the very limited incursion of Rivera (C's) in the political debate outside the Elections via Twitter.

There are also significant absences in Rivera's discourse concerning political topics. Unlike Pedro Sánchez (PSOE) and -to a lesser extent, but alsoIglesias (Podemos), Rivera (C's) hardly focuses his discourse on the debate over the economic recovery. If Sánchez (PSOE) reminds the budgetary cutbacks of Rajoy's office and criticises that recovery has only reached a few, Rivera (C's) shifts his focus to less specific notions -Spain, for instance, as aforementioned-; if Iglesias (Podemos) opts for reminding corruption cases or 
pointing at specific groups who have been neglected from the recovery process (such as the elder and the youth), Rivera (C's), simply, does not talk about it and simply refers to the notion of change that does not make differences between groups of Spaniards. Rather, the sensible change he praises must aim at the nation as a whole.

The scarce 27 mentions of Iglesias (Podemos) to political issues outside the electoral arena leave his 12 mentions to corruption as the main axis of his political discourse in this item. Four of them refer specifically to the 'Caja B' (the double accountability scandal that affected the Popular Party in Spain and that was being investigated at the time).

IV.4 Political language

We have categorised the political language of the discourses studied around two main approaches, 'The times are changin', and 'The times are not changin' that are mentioned 563 times in the total 1189 tweets studied -almost half the tweets studied refer explicitly to the notion of change. Positive approaches to change appear 470 times (around 4 out of 10 tweets studied refer to the notion of change), whereas the remaining 63 associate change to negative ideas or simply neglect it by praising continuity.

Aside from this notion of change that virtually monopolised the political discourses of the Regional Elections, there are other interesting recurrences in the speeches analysed. There are 328 tweets $(27,6 \%$ of the total 1189 studied) with generic references to the 'people', 'us' or 'everyone'; and 98 tweets $(8,4 \%)$ refer to traditional ideals, may them be generic ('more', 'better') or more specific ('democracy', 'diversity', 'innovation and modernity', 'freedom', 'union'). Politicians show appreciation or pride 68 times $(5,7 \%)$, and within the 'Miscellany' macrogroup there are interesting subgroups, such as the 127 mentions $(10,7 \%)$ to the abstract -not related to any measure in particular-notion of 'governance'. Let us now take a closer look into the specificities of every politician's discourse.

As in most of the political discourses studied for this paper, Mariano Rajoy's is mainly focused on the notion of change, with 157 mentions to this idea in his 388 tweets $(40,5 \%)$. The peculiarity of Rajoy's case is that his efforts are divided between praising the benefits of the changes done by the Government he leads and warning about the excesses of a non-sensible approach to other changes now. There are, in this respect, 45 mentions (almost 12\% of the tweets) to the general topic 'the perks of continuism', in which we have included those tweets that praise desirable economic, political and social values for Liberal standards, such as welfare (8 mentions), stability (14), achieving records (5), being competitive (4), or prosperity (3). In like manner, Rajoy (PP) devotes 59 mentions to remind his potential voters the downsides of a radical break from the usual standards of doing politics, with a special emphasis on the danger of populism and radicalism. He refers to these by repeating up to 3 times that the time for such political adventures is not now and even combining the words 'no, we can't' four times, which clearly resembles an intentional nemesis of Podemos' early motto 'of course we can' ('claro que podemos').

Regarding generic political ideals, there are recurring mentions in Rajoy's discourse to 'more and better' in different shades ('great' -12 times-, as a way to refer, for instance, to the country; or simply 'more' -18- and 'better' -12-). His only mentions to specific ideals are freedom (3) and innovation and modernity (1). The notion of change is also implicit in other recurring abstract notions of Rajoy's discourse, such as the reminders (10) to the goals achieved or to be achieved interpellations he does to his party to 'govern' (20), 'work' (8) or, sim- 
ply, 'make things happen' (8). Aside of those specific characteristics of his speech, Rajoy (PP) shares common points that are present in other discourses, such as some displays of appreciation (24) -especially to his political supporters, and more specifically in different political rallies, but also to the citizens who have made, in his view, economic recovery possible-, references to 'us' as a group (96) and interpellations to unity through the notion of 'everyone' (22).

Finally, it is noteworthy that Mariano Rajoy (PP) is the only politician, along with Pablo Iglesias (Podemos), who recurrently refers to the notion of 'the party'. His 13 mentions to the abstract notion of 'the party' outrank the only 4 references that Pablo Iglesias (Podemos) makes to his own.

As was the case, somehow, with the political topics discussed before, Pedro Sánchez' abstract notions that could be labelled within the category of 'political language' -as we have defined it before- are scarce and hinging upon very few notions. The 52 mentions to the notion of 'change' lead, as in most politicians studied, the ranking of abstract ideas also in Sánchez (PSOE), with 25 (almost 1 out of 10 of his tweets) explicit references to a need for 'renewal', 9 to the 'opportunities' that lie ahead, 8 about the 'future', and 3 on the 'hopeful anticipation' of the new era.

The other big block within the 'political language' category of Sánchez' discourse is the abstract reference to 'us' (up to 50 mentions, almost $20 \%$ of the tweets), whereas traditional approaches to political responsibility such as 'governance' (26), 'making' (7) or having a political 'project' (23) cope another 36 mentions (less than $15 \%$ of Sánchez' tweets).

As Rajoy (PP), Sanchez' sole reference to specific ideals goes to 'freedom' (quoted 5 times), which, along with the -also present in Rajoy (PP)- tokens of appreciation (8) to his potential voters end up configuring a discourse which, in terms of political language, does not offer significant differences -aside of the scarcity of references- from its traditional opponent's.

Rivera's discourse during the time studied is focused on the notion of change, though in his discourse this notion is addressed through a much wider range of approaches. Rivera (C's) mentions 'change' one way or another up to 246 times -most than half of his 452 items classified in this 'political language' category refer to the notion of change. However, as aforesaid, Rivera (C's) approaches the need for a change through a wide range of options: recalling the uniqueness of the opportunity that lies ahead of the voters -34 mentions to the notion of 'now' or 'today'-, 138 invitations to optimism -92 of which explicitly invoke the need for a change, but also a bunch of them praise hope (25), strength (8), dreams (3) and the recurring notion of nothing being impossible (9)-.

There is also an interesting line of enquiry in Rivera's praises of change that is not present in any of the traditional parties: the rejection of the past. Rivera (C's) expresses his opinion against old styles of politics consisting of taking sides, shows support to the generalised feeling the Spanish society has against certain ways of making politics, and criticises the widespread political strategy of the 'blame game'. As opposed to that, Rivera (C's) insists in proposing not only a change, but a sensible one. He praises agreements (4 explicit mentions), debate (6), dialogue (5), making politics (12), proposing measures (11), and recovering (the boost of) the working middle class (3).

Finally, although Rivera (C's) leaves room -just as all his political rivals do-for displays of appreciation (29), he-unlike Iglesias-adopts a political tone that has been traditionally closer to parties that rule or may rule, with explicit allusions to 'governance' (10), the political 'programme' (13), and the political 'project' (10). Also, he is the only politician who mentions the notion of 'transition' in a very particular way, as he never criticises the Spanish transition to de- 
mocracy but indirectly refers to the need to reshape it and give way to a 'new transition', more social and 'civic'.

Iglesias' references to the notion of change appear 62 times in 182 tweets, although, unlike Rivera (C's), his addresses to this idea are less varied and more focused on fewer ideas. He reminds the voters that 'the moment is now' (4 references) and that these elections are a historic opportunity (3); although the explicit references to change and renewal (32) prevail, most of the times associated to more emotional features such as 'thrilling' (6), 'yes, we can' (9), and 'courageous' (4).

Unlike Sánchez (PSOE) and Rivera (C's), Iglesias (Podemos) leaves room for 4 explicit mentions to the notion of a 'party'; although he follows his other colleagues approaches to Twitter as a vehicle to show tokens of appreciation (15) and to call to unity, in his case in a very wide range of forms: 'the people' (11), 'us' (27), 'everyone' (10) and 'comrades' (7). All of them coincide, nonetheless, in stressing the arrival of a new era and the importance of citizen participation to break away from old politics.

\section{Conclusions}

By 2015, Spanish politicians still did not seem to know how to make the most of Twitter, although some of them - notably Rajoy (PP) and Rivera (C's) were convinced they certainly needed to be there (and as profusely as possible). Most of the presence of prominent politicians in Twitter during the electoral campaign studied coincide with the account model that mainly conveys information (about activities of the party or the politician himself), but more particularly to show off about the virtues of their parties or the goals they have achieved.

Political communication during election periods is seldom in the hands of individuals and often in the hands of communication services and departments, but not in the case of Spain, where active politicians go online by themselves in a very amateur way.

Politicians did not use Twitter in the election submitted to study as a tool to interact to citizens but rather, as aforementioned, as a showcase of information/self-promotion, which confirms that, as Fuchs (2013) has pointed out, Twitter seems to be informative rather than communicative, and 'predominantly about entertainment, not about politics'. The only recurring way that the politicians studied relate with other accounts is via mentions, and even in these cases, there is a vast majority of references to party-colleagues, party-related people or political opponents.

The amount of references within the political circle is particularly striking when we compare it to the amount of times the politicians mention any other social actor. Although quite distantly, journalists/the media are the second most visible actors in the political discourses studied, especially for some politicians (notably, Rivera). However, this only encourages the theory of Twitter being used as a tool for the politician to show off.

Most candidates devote a great share of their discourse to the repetition of political mantras that are too abstract to be decoded as specific measures. All of them resort recurrently to the notion of 'change', either to warn from its dangers or praising its perks, use Twitter to show appreciation and pride -an indirect way of showing off, as it reveals support by the groups who are being thanked-, or try to create sides by referring repeatedly to the notion of 'us' or 'the people'. Shallow words are much more abundant than deeper, insightful ideas of pure 
Politics and proposals of specific measures, which redounds to the aforementioned thinness of Twitter in terms of encouraging debate.

Although most politicians profusely include self-mentions in their discourses, there are remarkable differences among them. The leaders of the new, emerging parties produce notably less self-mentions in their Twitter discourses than the leaders of the traditional parties, and the pattern is inversely proportional to the success the four parties had in the elections studied. This is consistent with Marwick's (2013) postulate that 'to high-status members of the tech community, blatant self-promotion is déclassé and very uncool'.

Although subtle attacks addressed at their competitors are present in all the politicians' campaigns in Twitter, direct references to parties or even specific politicians from their opponents follow different patterns in the elections studied. Both representatives of the two traditional parties are literally opposite poles: while Rajoy (PP) barely mentions specific names of parties or politicians outside his political spectrum, Sánchez' fixation with PP implies not only neglecting the emerging parties as a side effect, but also minimising the relative presence of his party in his own discourse. Iglesias (Podemos) and Rivera (C's) stay in between, acknowledging the presence of others, but not wasting too much time or space to mention them specifically.

The second part of Deltell's theory suggested that those who committed better and more with 2.0 communication strategies did not necessarily obtain better results. In our study we have observed cases that supported and contradicted this view. In the four cases submitted to study we have both examples of politicians who were very active in Twitter and obtained good results (Albert Rivera) and others who were even more active and saw how their results plummeted (Mariano Rajoy). Also, there were politicians who were not so active in Twitter during the time studied but his party obtained great results (Pablo Iglesias), and even a hybrid case of a politician who, comparatively, was not particularly active in Twitter and whose party lost three quarter million votes, but conquered more town halls and autonomic governments -mostly because of the support of the new, emerging parties.

Understanding the potentialities that Twitter make available to users has been traditionally a factor to explain the success of certain accounts, and trying to achieve a bigger reach by using hashtags is one of the recurring advices in this respect. However, the results obtained in this research indicate that an active use of hashtags -Rajoy (PP) used more than any other politician studied-does not necessarily involve better results in the Elections; probably because more variables -which are probably more impactful than knowing how to use Twitter as a communication vehicle-, such as political reputation or credibility, play a bigger role in what people decide to vote for.

In one of our hypotheses we echoed Deltell's (2012) assumption that small parties tend to commit more and better with 2.0 communication strategies. We focused on the two most emerging parties after the European Elections of May 2014 in Spain and established a comparison with the traditional parties regarding their political strategies in Twitter. The approach grouped them as 'Big fish' vs 'Underdogs', but reality has proved to be more complex than that.

On the one hand, maybe Ciudadanos and Podemos are no longer those 'small parties' Deltell referred to. They could have been ten years ago, when Ciudadanos was founded, or before the European Elections, when Podemos gained their first parliamentary seats. The political landscape in Spain has evolved since then towards the consolidation of these new parties as true alternatives to play a key role in Spanish politics. That can explain why, to certain extent, there are more similarities than differences in the discourses of the four 
politicians studied. They all faced the Regional and Autonomic Elections knowing that they could win and that they all had things to lose too. Hence, moderation, shallowness and political correctness to avoid scaring away potential voters prevailed.

On the other hand, however, by 2015 there were more novelties, rather than coincidences, in the discourse of the initially called 'Underdogs' (Podemos and Ciudadanos). For instance, Albert Rivera (C's) opted for moving away from criticism towards specific political opponents, as if when doing so he knew he would be echoing others' discourses. Iglesias (Podemos) did not exactly follow his lead, but he was not as obsessed as Sánchez (PSOE) with his main political opponent. Also, both Rivera (C's) and Iglesias (Podemos) tended to be less self-centred than their traditional counterparts Rajoy (PP) and Sánchez (PSOE).

Sánchez' approach to criticisms of others -or other, in his case, as most his criticisms focus on the other traditional alternative, the conservative party, only-also proves that it is difficult to group both PP and PSOE in the same category of 'Big Fish' regarding their performance in Twitter. Aside from the less obsessed-with-the-opponent campaign that Rajoy and his team produced in Twitter, he was much more active and less shallow than his Socialist counterpart. The results were devastating for both, though, and especially for Rajoy, which, nevertheless, does nothing but confirm Deltell's hypothesis of efficiency in Twitter and success in the Elections being two variables that not always are interconnected.

Roberto Gelado-Marcos (roberto.geladomarcos@ceu.es) Lecturer at CEU San Pablo University. He holds a PhD in Communication and Strategic Management of Knowledge in the Pontifical University of Salamanca (2012), an MA in Global Media in East London University (2005), and two BA in Translating and Interpreting in Salamanca University (2007) and in Journalism in the Pontifical University of Salamanca (2002). He teaches Audio Visual Narrative, Communication and Information Theory, and History of Journalism in the bilingual degrees in Communication in CEU San Pablo University.

Belén Puebla-Martínez (belen.puebla@urjc.es) Lecturer and researcher at the Universidad Rey Juan Carlos in Madrid (Spain) with a $\mathrm{PhD}$ in Communication Sciences from the same institution. She holds a degree in Journalism and Audiovisual Communication from the same university. He has taught various courses in the degrees of Journalism, Audiovisual Communication, Advertising, Business Administration and Management and Primary Education, both at the Universidad Rey Juan Carlos and at the Universidad Complutense of Madrid. She is a specialist in the study of Spanish television fiction and founder of the Visual interdisciplinary research group.

Rainer Rubira-García (rainer.rubira@urjc.es) Lecturer at Universidad Rey Juan Carlos in Madrid (Spain) and assistant researcher at the UNESCO Chair on Communication Research, within the same institution. He holds a Ph.D. degree and a Bachelor degree in Communication from Universidad Rey Juan Carlos and Universidad de La Habana, respectively. He has also worked for Universidad de La Habana (Cuba); INFOMED, Cuba's public health electronic information network and the Spanish Ministry of Communication. His research interests include communication theory, new media, Internet adoption and use, political communication and international communication.

\section{References}

Adorno, T.A. \& Horkheimer, M., 1979. The culture industry: enlightenment as mass deception. In O. B. Barrett \& C. Newbold (eds.). Approaches to media. A Reader. London: Arnold. pp.77-80.

Albæk, E., Van Dalen, A., Jebril, N. \& De Vreese, C., 2014. Political Journalism in Comparative Perspective. Cambridge: Cambridge University Press.

Bazeley, P. \& Jackson, K., 2013. Qualitative analysis with Nvivo. London: Sage Publications.

Bosco, A., 2013. Party Change in Southern Europe. London: Routledge.

Cebrián, E. y Vazquez, T., 2013. @ marianorajoy VS @ conRubalcaba: La campaña electoral de 2011 en las cuentas oficiales de Twitter de los candidatos del PP y del PSOE. In M. Römer (Coord.). Miradas a las pantallas en el bolsillo. Madrid: Universidad Camilo José Cela. pp.93- 108.

Chadwick, A. \& Stromer-Galley, J., 2016. Digital Media, Power, and Democracy in Parties and Election Campaigns: Party Decline or Party Renewal?. The International Journal of Press Politics, 21(3), pp.283-293. DOI: $10.1177 / 1940161216646731$

Coleman, S., 2017. Can the Internet Strengthen Democracy?. Malden: Polity Press. 
Coleman, S. \& Freelon, D., 2015. Handbook of Digital Politics. Cheltenham, UK: Edward Elgar Publishing.

Deltell L., 2012. Estudio del uso de Twitter, Facebook y YouTube en la campaña electoral de 2011 en España. El insólito caso de eQuo. In H. Cairo \& L. Finkel. Crisis y Cambios en las sociedades contemporáneas: retos teóricos y prácticos. Madrid: Universidad Complutense de Madrid.

Edhlund, B.M. \& McDougal, A. G., 2012. Nvivo 10 Essentials. Stockholm: Form \& Kunskap.

Fuchs, C., 2013. Social Media: A Critical Introduction. London: Sage Publications.

Espinel, O.A.P. \& Romero-Rodríguez, L.M., 2018. Polarización y demonización en la campaña presidencial de Colombia de 2018: Análisis del comportamiento comunicacional en Twitter de Gustavo Petro e Iván Duque. Humanidades, 9(1), pp.1-26. DOI:10.15517/h.v9i1.35343

García Ortega, C. \& Zugasti, R., 2012. Twitter en campaña: el caso de Mariano Rajoy en las elecciones generales de 2011. I Congreso Internacional en Comunicación Política y Estrategias de Campaña. Madrid.

Hesmondhalgh, D., 2013. The Cultural Industries. London: Sage Publications.

Lewis-Beck, M., Bryman, A. E. \& Futing Liao, T., 2004. The SAGE Encyclopedia of Social Science Research Methods. London: Sage Publications.

Marwick, A.E., 2013. Status Update: Celebrity, Publicity, and Branding in the Social Media Age. New Haven \& London: Yale University Press.

Paltridge, B., 2012. Discourse Analysis: An Introduction. New York: Bloomsbury.

Romero-Rodríguez, L.M., Aguaded, I. \& Gadea, W., 2015. De la demonización a la polarización: un análisis desde el discurso digital del gobierno y la oposición venezolana. Argos, 32(62), pp.97-117.

Romero-Rodríguez, L.M., De-Casas-Moreno, P. \& Torres-Toukoumidis, A., 2016). Dimensions and Indicators of the Information Quality in Digital Media. Comunicar, 24(49), pp.91-100. DOI: 10.3916/c49-2016-09

Swanson, D.L. \& Mancini, P., 1996. Politics, Media, and Modern Democracy: An International Study of Innovations in Electoral Campaigning and Their Consequences. Westport: Greenwood Publishing Group.

Stromer-Galley, J., 2014. Presidential Campaigning in the Internet Age. New York: Oxford University Press.

Twitter, o fim da política bipartidária e a ascensão do populismo. A campanha eleitoral espanhola em maio de 2015

RESUMO Introdução: O sistema político bipartidário aparentemente inabalável na Espanha começou a desmoronar após as eleições europeias de 2014, dando lugar a uma distribuição mais fragmentada de assentos. Esse efeito se consolidou nas eleições regionais de 2015 com a derrocada dos partidos tradicionais, PP e PSOE, e a ascensão de partidos populistas como o Podemos. Materiais e Métodos: Ao focar no discurso dos políticos espanhóis no Twitter, como uma das mais recentes ferramentas de comunicação política com as quais os políticos tiveram que aprender a lidar, este artigo oferece uma análise que triangula técnicas quantitativas e qualitativas. Resultados: Discutimos semelhanças e diferenças entre os partidos e os políticos para verificar se a comunicação 2.0 mudou e/ou melhorou o discurso político e levou à redistribuição de cadeiras parlamentares. Discussão: $\mathrm{O}$ artigo fomenta o interesse de pesquisas sobre o impacto das redes sociais e da implementação de diferentes estratégias de comunicação política a fim de se entender o colapso do bipartidarismo na Espanha.

PALAVRAS-CHAVE: Twitter, bipartidarismo, comunicação política, campanha eleitoral, Espanha.

This is an Open Access article distributed under the terms of the Creative Commons Attribution Non-Commercial License which permits unrestricted non-commercial use, distribution, and reproduction in any medium provided the original work is properly cited.

A produção desse manuscrito foi viabilizada através do patrocínio fornecido pelo Centro Universitário Internacional Uninter à Revista de Sociologia e Política. 